\title{
Peran Komisi Kepolisian Nasional Dalam Pengawasan Fungsional Polri
}

\author{
Mochammad Nasser \\ Universitas 17 Agustus 1945 Jakarta \\ Email: moch.nasser45@gmail.com
}

Received : 17 Mar 2021 | Revised : 25 Apr 2021 | Accepted : 2 May 2021| Published : 10 Jun 2021

\begin{abstract}
The Police Commission of the Republic of Indonesia which is responsible for assisting the President in determining the policies of the Indonesian National Police and other tasks related to the institution of the Indonesian National Police. The duties of the National Police Commission are regulated in Article 38 paragraph (1) of Law Number 2 of 2002 which as follows: "The National Police Commission for treasurers (a) assists the President in determining the policy of the State Police of the Republic of Indonesia and (2) provides considerations for the appointment of dismissal of the Chief of Police. "The authority of Kompolnas in accepting suggestions and complaints from the public regarding the performance of the police and conveying them to the President, is ambiguous. This is because authority is the power to do something that is given by a high institution in carrying out its duties and functions. However, the competent authority is more likely to be a task that supports the function of monitoring the performance of Polri to ensure the professionalism and independence of Polri. The authority of Kompolnas in receiving suggestions and complaints from the public related to the performance of the National Police can indeed be an input in the formulation of Polri's policy direction. However, the activities carried out in order to administer the authorities are more of a technical strategic assessment which supports the formulation of the strategic direction of the National Police. Based on the explanation that has been stated above, researchers are interested in carrying out scientific research in the field of law. The scientific research in the field of law is entitled "The Role of the National Police Commission in Polri's Functional Supervision". Research conducted using this type of juridical normative research, namely research that aims to examine the principles of law, legal systematics, legal history, and legal assets. The normative juridical approach is carried out by examining library materials or secondary data as the basic material for research.
\end{abstract}

Keywords: National Police Commission, Indonesian National Police

\begin{abstract}
ABSTRAK
Komisi Kepolisian Nasional secara prinsip bertugas untuk membantu Presiden dalam urusan penetapan arah kebijakan Kepolisian Negara Republik Indonesia dan tugas-tugas lain yang berhubungan dengan kelembagaan Kepolisian Negara Republik Indonesia. Tugas-tugas Komisi Kepolisian Nasional diatur dalam Pasal 38 ayat (1) UU Nomor 2 Tahun 2002 yang menentukan sebagai berikut "Komisi Kepolisian Nasional bertugas (a) membantu Presiden dalam nenetapkan arah kebijakan Kepolisian Negara Republik Indonesia dan (2) memberikan pertimbangan kepada Presiden dalam pengangkatan dan pemberhentian Kapolri." Wewenang Kompolnas dalam menerima menerima saran dan keluhan dari masyarakat mengenai kinerja
\end{abstract}


kepolisian dan menyampaikannya kepada Presiden, merupakan wewenang yang ambigu. Hal ini dikarenakan wewenang adalah kekuasaan untuk melakukan sesuatu yang diberikan oleh lembaga yang tinggi dalam menjalankan tugas dan fungsi. Namun demikian wewenang yang disebutkan tersebut lebih cenderung merupakan tugas yang menunjang fungsi pengawasan fungsional atas kinerja Polri untuk menjamin profesionalitas dan kemandirian Polri. Wewenang kompolnas dalam menerima menerima saran dan keluhan dari masyarakat terkait kinerja Polri memang dapat menjadi masukan dalam penyusunan arah kebijakan Polri. Namun kegiatan-kegiatan yang dilakukan dalam rangka memenuhi wewenang tersebut lebih bersifat teknis daripada strategis yang menunjang penyusunan arah kebijakan strategis Polri. Berdasarkan paparan yang telah kemukakan di atas, peneliti tertarik untuk melakukan suatu penelitian ilmiah di bidang hukum. Penelitian ilmiah di bidang hukum tersebut berjudul "Peran Komisi Kepolisian Nasional dalam Pengawasan Fungsional Polri”. Penelitian yang dilakukan ini menggunakan Jenis penelitian Yuridis Normatif, yaitu penelitian yang bertujuan untuk menelaah asas hukum, sistematika hukum, sejarah hukum, dan sinkronisasi hukum. Pendekatan yuridis normatif dilakukan dengan cara meneliti bahan Pustaka atau data Sekunder sebagai bahan dasar untuk diteliti.

Kata Kunci: Komisi Kepolisan Nasional, Kepolisian Negara Republik Indonesia

\section{PENDAHULUAN}

Salah satu aspek kehidupan bersama dalam bingkai kehidupan bermasyarakat, berbangsa dan atau bernegara yang juga dipengaruhi oleh asas negara hukum adalah aspek penataan dan pengorganisasian kehidupan bernegara dan praktik penyelenggaraan negara. Dalam konteks aspek kehidupan bernegara, asas negara hukum mempengaruhi segenap aspek pembentukan organ-organ negara, kedudukan, wewenang, tugas, fungsi dan struktur organisasi negara. Pengaruh asas negara hukum terhadap pengorganisasi kekuasaan negara dan struktur organ-organ negara dapat bekerja (berlangsung) melalui salah satu unsur negara hukum sebagai turunan (derivasi) dari asas negara hukum yakni asas pemisahan kekuasaan (separation of power). ${ }^{1}$ Asas pemisahan kekuasaan (separation of power) menjadi salah satu asas (prinsip) dalam pengorganisasian negara moderen yang bercorak demokratis. Pada zaman sekarang, negara-negara moderen berpedoman pada asas pemisahan kekuasaan (separation of power) dalam pengorganisasian kekuasaan negara. Oleh sebab itu, berdasarkan asas negara hukum dapat dibangun struktur ketatanegaraan dan sistem pemerintahan demokratis yang diharapkan dapat memberikan pelayanan terhadap masyarakat dengan tujuan untuk menyelenggarakan kesejahteraan umum. Negaranegara demokratis seperti Amerika juga berpedoman pada asas pemisahan kekuasaan (separation of power) dalam menata struktur organisasi negaranya. Sebagai negara hukum demokratis, Indonesia juga menganut prinsip pemisahan kekuasaan dalam mengorganisir kekuasaan negara Republik Indonesia.

Salah satu organ negara Republik Indonesia yang disebut dalam UUD 1945 adalah Kepolisian Negara Republik Indonesia. Pasal 30 ayat (4) Undangundang Dasar 1945 menyebutkan sebagai berikut "Kepolisian Negara Republik Indonesia sebagai alat negara yang menjaga keamanan dan ketertiban masyarakat bertugas melindungi, mengayomi, melayani masyarakat serta menegakkan hukum." Fungsi (tugas) melindungi, mengayomi, melayani masyarakat dan menegakkan hukum seperti

${ }^{1}$ Azhary, Negara Hukum Indonesia Analisis Normatif tentang Unsur-unsurnya, Cet. I, Jakarta: UI Press, 1995, hlm. 46. 
dikemukakan di atas adalah bagian dari fungsi (tugas) negara. Secara definitif, alatalat perlengkapan suatu negara atau yang lazim disebut sebagai lembaga negara adalah institusi-institusi yang dibentuk guna melaksanakan fungsi-fungsi negara. ${ }^{2}$ Sesuai dengan fungsi (tugas) yang disebut dalam ketentuan Pasal 30 ayat (4) UUD 1945 yang dikemukakan di atas, Kepolisian Negara Republik Indonesia adalah institusi organ negara atau lembaga negara). Sebagai lembaga negara, Kepolisian Negara Republik Indonesia sama seperti lembaga negara yang lain yakni MPR, PRESIDEN, DPR, DPD, MA, MK, BPK, Komisi Yudisial dan lain-lain meskipun dengan kedudukan yang berbeda dari organ-organ negara yang dikemukakan di atas.

Lembaga negara utama (main state organ) yang disebut di atas adalah MPR, PRESIDEN, DPR, DPD, MA, MK, BPK dan Komisi Yudisial. Beberapa lembaga negara utama yang sudah lazim dikenal dalam sistem ketatanegaraan Indonesia sebelum amandemen adalah MPR, PRESIDEN, DPR, BPK dan MA. Ketiga lembaga negara yang lain yakni Mahkamah Konstitusi, Dewan Perwakilan Daerah (DPD) dan Komisi Yudisial dibentuk pascaamandemen UUD 1945.

Berdasarkan ketentuan Pasal 30 ayat (4) UUD 1945, Kepolisian Negara Republik Indonesia memiliki kedudukan yang sangat kuat sebagai lembaga negara pembantu (auxiliary state organ) karena ditetapkan oleh UUD 1945. Kewenangannya diatur dalam undang-undang. Ketentuan konstitusional yang mengatur fungsi Kepolisian Negara Republik Indonesia membuatlembaga negara ini memiliki kedudukan konstitusional dalam sistem ketatanegaraan Indonesia sama seperti MPR, PRESIDEN, DPR, DPD, MA, MK, BPK dan Komisi Yudisial.

Ketentuan konstitusional Pasal 30 ayat (4) UUD 1945 yang dikemukakan di atas menetapkan fungsi kepolisian negara Republik Indonesia sebagai institusi (organ negara atau lembaga negara pembantu atau auxiliary state organ) dengan berbagai macam tugas yang bersentuhan dengan berbagai aspek kehidupan bermasyarakat dan bernegara. Berbagai macam fungsi Kepolisisan Negara Republik Indonesia seperti diatur dalam Pasal 34 ayat (4) UUD 1945 menunjukkan betapa luas fungsi-fungsi kenegaraan dan atau pemerintahan yang termasuk dalam ruang lingkup fungsi Kepolisian Negara Republik Indonesia. Fungsi kepolisian negara Republik Indonesia sebagai organ negara (lembaga negara atau organ negara) berdasarkan ketentuan Pasal 30 ayat (4) UUD 1945 meliputi:

1. Menjaga keamanan dan ketertiban masyarajat;

2. Bertugas melindungi, mengayomi, dan melayani masyarakat, dan

3. Menegakkan hukum.

Ketentuan Pasal 30 ayat (4) UUD 1945 yang dikemukakan di atas mengatur fungsi Kepolisian Negara Republik Indonesia dalam garis besar semata-mata. Rincian tugas dan wewenang Kepolisian Negara Republik Indonesia sebagai suatu institusi (lembaga negara atau organ negara) belum diatur sama sekali. Kedudukan, tugas dan wewenang Kepolisian Negara Republik Indonesia sebagai suatu institusi (lembaga negara atau organ negara) diatur dengan undang-undang. Pengaturan kedudukan, tugas dan wewenang Kepolisian Negara Republik Indonesia sebagai institusi (organ negara atau lembaga negara) yang harus diatur dalam undang-undang adalah perintah dari Pasal 30 ayat (5) UUD 1945 yang menetapkan sebagai berikut:

${ }^{2}$ Firmansyah Arifin d.k.k., Lembaga Negara dan Sengketa Kewenangan Antarlembaga Negara Jakarta: Konsorsium Reformasi Hukum Nasional, 2005.hlm. 30. 
"Susunan dan kedudukan Tentara Nasional Indonesia, Kepolisian Negara Republik Indonesia, hubungan kewenangan Tentara Nasional Indonesia dan Kepolisian Negara Republik Indonesia di dalam menjalankan tugasnya, syaratsyarat keikutsertaan warga negara dalam usaha pertahanan dan keamanan negara, serta hal-hal yang terkait dengan pertahanan dan keamanan diatur dengan undang-undang."

Ketentuan Pasal 30 ayat (5) UUD 1945 yang dikemukakan di atas diatur lebih lanjut dalam Undang-undang Nomor 2 Tahun 2002 tentang Kepolisian Negara Republik Indonesia. Undang-undang yang disebut di atas mengatur berbagai hal tentang Kepolisian Negara Republik Indonesia sebagai suatu institusi atau lembaga negara (organ negara) seperti struktur organisasi kepolisian negara, wewenang dan tugas-tugas kepolisian negara Republik Indonesia dan lain-lain dalam sistem ketatanegaraan Republik Indonesia. Pengaturan Kedudukan, fungsi, tugas dan wewenang Kepolisian Negara Republik Indonesia berdasarkan undang-undang mengandung arti kewenangan lembaga negara ini diperoleh dari undang-undang secara atributif.

Secara hierarkhis, dalam sistem ketatanegaraan Indonesia, kedudukan Kepolisian Negara Republik Indonesia berada di bawah Presiden. Oleh karena itu, penulis dapat menafsirkan bahwa Kepolisian Negara Republik Indonesia sebagai lembaga negara pembantu (auxiliary state organ) bertugas untuk membantu Presiden. Pasal 8 ayat (1) UU Nomor 2 Tahun 2002 sebagai berikut "Kepolisian Negara Republik Indonesia berada di bawah Presiden." Kedudukan Kepolisian Negara Republik Indonesia yang berada di bawah Presiden merupakan konsekuensi fungsinya yang termasuk dalam fungsi pemerintahan seperti dikemukakan di atas. Sebagaimana diketahui, dalam sistem ketatanegaraan Indonesia, kekuasaan eksekutif tertinggi terletak pada lembaga Presiden. Pasal 2 ayat (1) UUD 1945 menentukan sebagai berikut "Presiden Republik Indonesia memegang kekuasaan pemerintahan menurut Undang-undang Dasar." Ketentuan Pasal 2 ayat (1) UUD 1945 di atas menempatkan dan memusatkan pertanggungjawaban atas kekuasaan eksekutif dalam sistem ketatanegaraan dan sistem pemerintahan Indonesia pada lembaga Presiden.

Fungsi Kepolisian Negara Republik Indonesia yang ditetapkan dalam ketentuan pasal-pasal yang dikemukakan di atas diatur lebih lanjut dalam pasalpasal UU Nomor 2 Tahun 2002. Pasal 13 UU Nomor 2 Tahun 2002 menentukan sebagai berikut "Tugas pokok Kepolisian Negara Republik Indonesia adalah (1) memelihara keamanan dan ketertiban masyarakat, (2) menegakkan hukum dan (3) memberikan perlindungan, pengayoman dan pelayanan kepada masyarakat. Sesuai dengan tugas pokok yang dikemukakan di atas, Pasal 14 ayat (1) UU Nomor 2 Tahun 2002 menentukan lebih lanjut tugas pokok Kepolisian Negara Republik Indonesia. Sesuai dengan ketentuan Pasal 14 ayat (1) UU Nomor 2 Tahun 2002, tugas pokok Kepolisian Negara Republik Indonesia mencakup ruang lingkup yang sangat luas.

Arah kebijakan kepolisian nasional Indonesia ditetapkan oleh Presiden Republik Indonesia sebagai puncak kekuasaan eksekutif tertinggi dalam sistem ketatanegaraan dan sistem pemerintahan Indonesia. Untuk menetapkan arah kebijakan Kepolisian Negara Republik Indonesia, Presiden Republik Indonesia dibantu oleh suatu lembaga negara yang disebut Komisi Kepolisian Nasional. Komisi Kepolisian Nasional adalah suatu lembaga negara pembantu (auxiliary state organ) yang memiliki fungsi tertentu yakni membantu tugas Presiden dalam merumuskan arah kebijakan kepolisian nasional. Keberadaan Komisi Kepolisian Nasional diatur dalam UU Nomor 2 Tahun 2002. Pasal 37 ayat (1) UU Nomor 2 Tahun 2002 menyebutkan sebagai 
berikut "Lembaga Kepolisian Nasional yang disebut Komisi Kepolisian Nasional berkedudukan di bawah dan bertanggung jawab kepada Presiden." Sesuai dengan Pasal 37 UU Nomor 2 Tahun 2002, lembaga negara kepolisian nasional yang disebut dengan nama Komisi Kepolisian Nasional ditetapkan atau dibentuk dengan Peraturan Presiden. Pasal 37 ayat (2) UU Nomor 2 Tahun 2002 menyebutkan sebagai berikut "Komisi Kepolisian Nasional sebagaimana dimaksud dalam ayat (1) dibentuk dengan Keputusan Presiden."

Komisi Kepolisian Nasional secara prinsip bertugas untuk membantu Presiden dalam urusan penetapan arah kebijakan Kepolisian Negara Republik Indonesia dan tugas-tugas lain yang berhubungan dengan kelembagaan Kepolisian Negara Republik Indonesia. Tugas-tugas Komisi Kepolisian Nasional diatur dalam Pasal 38 ayat (1) UU Nomor 2 Tahun 2002 yang menentukan sebagai berikut "Komisi Kepolisian Nasional bertugas (a) membantu Presiden dalam nenetapkan arah kebijakan Kepolisian Negara Republik Indonesia dan (2) memberikan pertimbangan kepada Presiden dalam pengangkatan dan pemberhentian Kapolri." Garis besar tugas Komisi Kepolisian Nasional adalah seperti dikemukakan di atas. Akan tetapi, rincian wewenang dan tugas-tugas Komisi Kepolisian Nasional diatur lebih lanjut dalam Pasal 38 ayat (2) UU Nomor 2 Tahun 2002 yang mengatur sebagai berikut:

"Dalam melaksanakan tugas sebagaimana dimaksud dalam ayat (1), Komisi Kepolisian Nasional berwenang untuk :

a. Mengumpulkan dan menganalisis data sebagai bahan pemberian saran kepada Presiden yang berkaitan dengan anggaran Kepolisian Negara Republik Indonesia, dan pengembangan sarana dan prasarana Kepolisian Negara Republik Indonesia,

b. Memberikan saran dan pertimbangan lain kepada Presiden dalam upaya mewujudkan Kepolisian Negara Republik Indonesia yang profesional dan mandiri,

c. Menerima saran dan keluhan dari masyarakat mengenai kinerja kepolisan dan menyampaikannya kepada Presiden."

Fungsi, Wewenang dan Tugas Kompolnas diatur dalam Peraturan Presiden Nomor 17 Tahun 2005 tentang Komisi Kepolisian Nasional. Setelah berjalan selama 6 (enam) tahun, Peraturan Presiden Nomor 17 Tahun 2005 dicabut karena fungsi, wewenang dan tugas Kompolnas dipandang perlu untuk disesuaikan dengan kebutuhan untuk mewujudkan profesionalisme, akuntabilitas dan kemandirian Kompolnas. Pencabutan Pertaruran Presiden Nomor 17 Tahun 2005 ditetapkan berdasarkan Peraturan Presiden Nomor 17 Tahun 2011 tentang Komisi Kepolisian Nasional. Dalam Pasal 3 ayat (1) Peraturan Presiden Nomor 17 Tahun 2011 disebutkan "Kompolnas melaksanakan fungsi pengawasan fungsional terhadap kinerja Polri untuk menjamin profesionalisme dan kemandirian Polri."

Jika berpedoman pada ketentuan Pasal 37 UU Nomor 2 Tahun 2002, Lembaga Kepolisian Nasional yang disebut Komisi Kepolisian Nasional adalah suatu organ negara yang berkedudukan dan bertanggung jawab kepada Presiden. Artinya, Kompolnas adalah lembaga negara pembantu (auxiliary state organ) yang berfungsi membantu pelaksanaan tugas-tugas tertentu Presiden sesuai dengan ketentuan undangundang. Ruang lingkup tugas Kompolnas membantu Presiden untuk menetapkan arah kebijakan Kepolisian Negara Republik Indonesia dan memberikan pertimbangan kepada Presiden dalam pengangkatan dan pemberhentian Kapolri. Dengan demikian, 
wewenang dan tugas Kompolnas sebagai lembaga negara pembantu Presiden (auxiliary state organ) difokuskan kepada kedua macam tugas yang disebutkan di atas.

Keluhan yang disampaikan anggota masyarakat adalah tentang kelemahan yang menjadi kendala dalam pelaksanaan tugas dan wewenang Kompolnas sebagai organ negara pembantu Presiden dalam bidang tugas tertentu yang bersifat khusus dan terbatas pada hal tertentu. Kelemahan Kompolnas yang disampaikan masyarakat seperti dikemukakan di atas berkaitan dengan ketidakjelasan informasi mengenai tata cara mengajukan keluhan/saran terhadap (kepada) Kompolnas. ${ }^{3}$ Masyarakat yang hendak mengajukan atau mengemukakan keluhan terhadap Kompolnas tidak tahu atau tidak paham prosedur pengaduan atau keluhan yang harus ditempuh.

Ada berbagai macam keluhan dan kritik yang dialamatkan kepada Kompolnas yang menunjukkan bahwa lembaga (organ) negara pembantu tersebut dianggap masyarakat belum dapat melaksanakan tugasnya membantu untuk Presiden dalam rangka (1) menetapkan arah kebijakan Kepolisian Negara Republik Indonesia dan (2) memberikan pertimbangan kepada Presiden dalam pengangkatan dan pemberhentian Kapolri." Dengan perkataan lain, ada masalah yang masih harus diperbincangkan dan terutama untuk diteliti berkenaan dengan wewenang dan tugas Kompolnas sebagai lembaga (organ) negara pembantu Presiden pada bidang tugas tertentu yang bersifat khusus dan terbatas.

Berdasarkan paparan latar belakang masalah yang peneliti kemukakan di atas, peneliti tertarik untuk melakukan suatu penelitian ilmiah di bidang hukum. Penelitian ilmiah di bidang hukum tersebut berjudul "Peran Komisi Kepolisian Nasional dalam Pengawasan Fungsional Polri”

\section{PEMBAHASAN}

Penelitian yang dilakukan penulis menggunakan 3 (tiga) jenis teori yaitu Negara Hukum Demokratis sebagai teori dasar, teori Pemisahan Kekuasaan sebagai teori menengah, dan teori Sistem Pemerintahan sebagai teori terapan.

\section{Teori Negara Hukum Demokratis}

Pandangan mengenai Negara hukum sudah ada pada saat filsuf Yunani kuno yaitu Plato yang memaparkan bahwa suatu penyelenggaraan negara yang baik hanya akan bisa berjalan apabila didasarkan atas aturan hukum yang baik. Pemikiran tersebut ada saat plato dengan konsepnya menyatakan "bahwa penyelenggaraan negara yang baik adalah yang didasarkan pada pengaturan (hukum) yang baik yang disebut dengan istilah nomoi". 4

Negara hukum menurut Aristoteles yang telah dikutip oleh Moh. Kusnardi yaitu suatu negara hukum ada akibat polis yang memiliki wilayah negara kecil, contohnya adalah kota yang memiliki sedikit penduduk, bukan seperti negara sekarang yang terdiri dari penduduk yang banyak dan memiliki wilayah luas (vlakte staat). Polis itu menjadikan Musyawarah untuk dilakukan dalam setiap kegiatan urusan bernegara (Ecclesia), jadi semua warga negara ikut serta untuk urusan menjalankan Negara. ${ }^{5}$

\footnotetext{
${ }^{3}$ Komisi Kepolisian Nasional, Penilaian Stakeholders Terhadap Kinerja Kompolnas Tahun 2010 Jakarta: Kompolnas, 2010, hlm. 57.

${ }^{4}$ Titik Triwulan Tutik, Pokok-pokok Hukum Tata Negara Indonesia, Jakarta: Prestasi Pustaka, 2006, hlm. 61 .

${ }^{5}$ Moh. Kusnardi, Hukum Tata Negara Indonesia, Jakarta: Sinar Bakti, 1987, hlm. 153.
} 
Sebagai asas kehidupan bernegara yang sangat penting, asas negara hukum mengandung konsekuensi yang sangat luas terhadap berbagai aspek negara dan kehidupan bernegara. Asas negara hukum mengandung konsekuensi terhadap penataan susunan atau struktur organisasi negara, fungsi, tugas dan wewenang lembaga-lembaga negara. Oleh sebab itu, asas negara hukum mengandung konsekuensi atau memiliki pengaruh terhadap semua aspek yang berkaitan dengan praktik penyelenggaraan negara dan kehidupan bermasyarakat, berbangsa dan bernegara. Asas negara hukum moderen seperti dikenal pada zaman sekarang berkembang secara bertahap dalam rentang waktu yang sangat panjang. Asas negara hukum sudah dikenal 2500 (dua ribu lima ratus) tahun sebelum masehi dalam peradaban Yunani Kuno. ${ }^{6}$

Istilah lain yang sering dipergunakan dalam konsep negara hukum yaitu rechstaat dan rule of law. Jika dilihat sejenak istilah-istilah tersebut memiliki pengertian yang sama, namun sebenarnya ada pembeda yang cukup penting. Kedua istilah tersebut dalam konsep negara hukum mengalami perkembangan, perkembangan dalam segi teoritis koseptual dan juga praktisi operasional. ${ }^{7}$ Menurut Philipus M. Hadjon yang dikutip oleh El-Muhtaj, rechtstaat sifatnya revolusioner hal ini dikarenakan lahir akibat reaksi yang timbul dalam menentang absolutism yang tidak menghargai eksistensi hak asasi manusia. Sedangkan the rule of law berkembang secara evolusioner. ${ }^{8}$

Konsep Rechtstaat berkembang pada sistem hukum eropa continental (Civil Law), sementara itu konsep the rule of law (Common Law) berkembang pada sistem hukum anglo-saxon. Karakteristik dari sistem hukum civil law ialah administrative, sementara itu karakteristik sistem hukum common law ialah judisial. ${ }^{9}$

Immanuel Kant, Paul Laband, Julius Stahl, Fichte. mempelopori konsep negara hukum dalam sistem hukum civil law. Jimly Assiddiqie mengutip pendapat Julius Stahl yang menyatakan jika konsep negara hukum memuat empat unsur penting, yang terdiri dari: $:^{10}$

a. Adanya perlindungan Hak Asasi Manusia.

b. Adanya pembagian kekuasaan.

c. Menjalankan pemerintana berdasaran undang-undang.

d. Adanya peradilan tata usaha negara.

Negara hukum dalam sistem hukum common law yang dikembangkan oleh A.V. Dicey. Menurut beliau seperti yang dikutip oleh Titik Triwulan, konsep rule of law memiliki tiga poin, yaitu: ${ }^{11}$

6 Hotma P. Sibuea, Asas Negara Hukum, Peraturan Kebijakan dan Asas-asas Umum Pemerintahan Yang Baik, Jakarta: Erlangga, 2010, hlm. 10

${ }^{7}$ Mexsasai Indra, Dinamika Hukum Tata Negara Indonesia, Bandung: Refika Aditama, 2011, hlm.23.

${ }^{9}$ Philipus Hadjon, Perlindungan Hukum bagi Rakyat di Indonesia, Jakarta: Bina Ilmu, 1987, hlm.72.

10 Jimly Assiddiqie, Gagasan Negara Hukum Indonesia, https://pngunungsitoli.go.id/assets/image/files/Konsep_Negara_Hukum_Indonesia.pdf, diakses pada tanggal 2 juli 2020, pukul 01:32 WIB.

${ }^{11}$ Titik Triwulan, Op. Cit., Hlm. 61. 
a. Supremasi hukum;

b. Persamaan dihadapan hukum;

c. Hak perorangan yang didasarkan pada konstitusi.

Negara Kesatuan Republik Indonesia didalam penjelasan UUD 1945 merupakan negara yang berdasarkan atas hukum, bukan berdasarkan atas kekuasaan. ${ }^{12}$

Pancasila sebagai cita hukum bangsa Indonesia menjadikan sebagai nilai dasar ataupun landasan bagi manusia dalam bersikap dan berperilaku dalam benegara. Cita hukum berada dalam alam nilai dan tidak memiliki bentuk yang jelas sehingga belum berada dalam alam norma-norma. Cita hukum berfungsi sebagai bintang pemandu. ${ }^{13}$

Sebagai cita hukum yang bukan sekedar nilai-nilai atau norma biasa tetapi Pancasila merupakan staatsfundamentalnorm, menjadikan Pancasila sebagai dasar dari suatu tata hukum tanpa adanya cita hukum maka suatu tata hukum juga tidak akan ada. Sehingga Pancasila sangat berperan dalam pembentukan tata hukum di Indonesia.

Staatsfundamentalnorm atau norma fundamental negara adalah norma hukum fundamental yang berfungsi sebagai pedoman dalam membentuk suatu norma hukum yang tingkatannya lebih rendah. Selain berperan sebagai fungsi sebagai dasasr dalam pembentukan norma hukum, Pancasila juga memiiki fungsi regulative.

Negara hukum Pancasila merupakan sumber yang berasal darii nilai-nilai social dan budaya bangsa Indonesia yang penegasannya adalah menjadikan Pancasila sebagai Dasar Negara. ${ }^{14}$ Untuk itu maka Pancasila berfungsi sebagai cita hukum bagi produk hukum di Indonesia.

Asas demokrasi dan asas negara hukum merupakan dua asas yang harus dipergunakan dalam kehidupan bermasyarakat, berbangsa dan bernegara. Apabila demokrasi dan nomokrasi dianut bersama-sama dalam suatu negara, keduanya akan melahirkan konsep negara hukum yang demokratis. ${ }^{15}$ Dalam konsep negara hukum yang demokratis terkandung makna demokrasi diatur dan dibatasi oleh aturan hukum, sedangkan substansi hukum itu sendiri ditentukan dengan cara-cara yang demokratis berdasarkan konstitusi. ${ }^{16}$

Demokrasi adalah bentuk atau mekanisme pemerintahan suatu negara sebagai upaya mewujudkan kedaulatan rakyat atau warganegara atas negara untuk dijalankan oleh pemerintah negara tersebut. Demokrasi, baik langsung maupun tidak langsung bersendi pada rakyat yang memerintah dirinya sendiri sehingga antara yang memerintah dan yang diperintah bersifat identik yaitu sama-sama rakyat. ${ }^{17}$ Keterlibatan rakyat dalam setiap aspek menyelenggarakaan negara merupakan konsekuensi dari suatu negara demokrasi modern. Oleh sebab itu, dalam perkembangan praktek penyelenggaraan negara demokrasi modern, doktrin atau ajaran kedaulatan rakyat kemudian berkembang menjadi doktrin yang memberikan dasar pembenaran kepada penyelenggaraan demokrasi modern tersebut. Paimin

${ }^{12}$ Diana Halim Koentjoro, Hukum Administrasi Negara, Bogor Selatan: Ghalia Indonesia, 2004, hlm. 34-5.

${ }^{13}$ Hotma P Sibuea, Kapita Selekta Hukum Tata Negara, Jakarta: ATA.Print, 2007, hlm.16.

${ }^{14}$ Aloysius R. Entah, Op.Cit., hlm.536.

${ }^{15}$ Janedjri M. Gaffar, Demokrasi Konstitusional: Praktik KetatanegaraanIndonesia SetelahPerubahan UUD 1945, Jakarta: Konstitusi Press, 2012, hlm. 6.

${ }^{16}$ Ibid., hlm. 7.

${ }^{17}$ Jimly Asshiddiqie, Pengantar Ilmu Hukum Tata Negara, Jakarta: Rajawali Pers, 2014, hlm. 103. 
Napitupulu lebih lanjut berpendapat bahwa "ajaran kedaulatan rakyat yang berintikan pemerintah dari, oleh dan untuk rakyat selanjutnya melahirkan teori negara demokrasi yakni suatu pemerintah yang dijalankan oleh wakil-wakil rakyat."18

Sejarah menunjukkan bahwa ide demokrasi pernah dianggap sebagai konsep pemerintahan yang tidak ideal. Hal ini diantaranya disebabkan oleh di-antinomikannya ide demokrasi dan negara hukum (rule of law/rechtstaat) sebagai pilihan, sehingga yang terjadi ialah antara pemerintahan yang didasarkan pada negara hukum namun tidak demokratis, atau sebaliknya, negara yang demokratis menjadi chaos karena kebebasan dihasilkan tanpa adanya keteraturan dan kepastian. Prinsip demokrasi menyiratkan bahwa rakyatlah yang pada hakikatnya memiliki kekuasaan tertinggi dalam suatu negara. Sedangkan dalam kedaulatan hukum, kekuasaan tertinggi dalam suatu negara bersumber dari hukum. Dalam hal ini, hukum dilihat secara formal, yaitu dari sisi bentuknya sebagai produk yang mengikat segenap warga negara. Dengan demikian, hukum dapat saja ditentukan oleh penguasa untuk kepentingan kekuasaannya, namun belum tentu sesuai dengan perasaan keadilan masyarakat. ${ }^{19}$ Oleh karena itu, antara prinsip kedaulatan rakyat (demokrasi) dan kedaulatan hukum (nomokrasi) hendaklah diselenggarakan secara beriringan sebagai dua sisi dari mata uang yang sama sehingga yang tercipta adalah negara hukum yang demokratis (demokratische rechtstaat) dan sekaligus adalah Negara Demokrasi yang berdasar atas hukum (constitutional democracy). ${ }^{20}$

Secara garis besar, demokrasi dan nomokrasi adalah dua asas yang diperlukan untuk menciptakan negara hukum yang berkeadilan. Hal ini dikarenakan fungsi dari keduanya yang dapat menjembatani kepentingan dari negara maupun rakyatnya. Sebagaimana dinyatakan bahwa "democracy and rule of law can be seen as two different means to overcoming the inherent contradiction between state and society." 21 Namun untuk dapat mewujudkan tujuan negara yang sesungguhnya, Pancasila sebagai cita hukum di Indonesia tentunya harus dijadikan landasan penyelenggaraan negara hukum demokratis. Hal ini dilakukan untuk dapat menyesuaikan nilai-nilai kebebasan dan persamaan dalam demokrasi yang diterapkan di Indonesia untuk bertumpu pada asas kekeluargaan.

\section{Teori Pemisahan Kekuasaan}

Pada prinsipnya, konstitusi atau undang-undang dasar suatu negara antara lain merupakan pencatatan (registrasi) pembagian kekuasaan di dalam suatu negara. Pembagian kekuasaan menurut fungsinya menunjukkan perbedaan antara fungsifungsi pemerintahan yang bersifat legislatif, eksekutif dan yudikatif yang lebih dikenal sebagai Trias Politika. ${ }^{22}$

Trias Politika adalah anggapan bahwa kekuasaan negara terdiri atas tiga macam kekuasaan: Pertama, kekuasaan legislatif atau kekuasaan membuat undang-undang (dalam peristilahan baru sering disebut rule making function); kedua, kekuasaan

\footnotetext{
${ }^{18}$ Hotma P. Sibuea, Ilmu Negara, Jakarta:Erlangga, 2014, hlm. 229.

${ }^{19}$ Janedjri M. Gaffar, Op. Cit., hlm. 5.

${ }^{20}$ Jimly Asshiddiqie, Konstitusi..., Op. Cit., hlm. 71.

${ }^{21}$ Francis Sejersted, "Democracy and the Rule of Law: Some Historical Experiences of Contradictions in the Striving for Good Government", dalam Constitutionalism and Democracy (Edited by Jon Elster and Rune Slagstad), Cambridge, UK: Cambridge University Press, 1997, hlm. 132.

22 Bagir Manan, Pertumbuhan dan Perkembangan Konstitusi Suatu Negara, Bandung: Mandar Maju, , 1995, hlm. 78-79
} 
eksekutif atau kekuasaan melaksanakan undang-undang (rule application function); ketiga kekuasaan yudikatif atau kekuasaan mengadili atas pelanggaran undang-undang (rule adjudication function). Trias politika adalah suatu prinsip normatif bahwa kekuasaan-kekuasaan (function) ini sebaiknya tidak diserahkan kepada orang yang sama untuk mencegah penyalahgunaan kekuasaan oleh pihak yang berkuasa. Dengan demikian hak-hak asasi warga negara lebih terjamin. ${ }^{23}$

Montesquieu mengemukakan bahwa kemerdekaan hanya dapat dijamin jika ketiga fungsi kekuasaan tidak dipegang oleh satu orang atau badan tetapi oleh ketiga orang atau badan yang terpisah. Dikatakan olehnya "kalau kekuasaan legislatif dan kekuasaan eksekutif disatukan dalam satu orang atau dalam satu badan penguasa, maka tak akan ada kemerdekaan, akan menjadi malapetaka jika seandainya satu orang atau satu badan, apakah terdiri dari kaum bangsawan ataukah dari rakyat jelata, diserahi menyelenggarakan ketiga kekuasaan tersebut, yakni kekuasaan membuat undang-undang, menyelenggarakan keputusan- keputusan umum dan mengadili persoalan-persoalan antara individu-individu. ${ }^{24}$

Teori pembagian kekuasaan sangat diperlukan dalam sistem suatu ketatanegaraan, dikarenakan para penyelenggara negara mereka bukanlah manusia malaikat, tetapi manusia mempunyai kecenderungan memperluas dan memperpanjang kekuasaannya dengan mengabaikan hak-hak rakyat. Untuk itu diperlukan suatu sistem saling mengawasi secara seimbang (check and balance). Operasionalisasi dari teori check and balance menurut fuadi, dapat dilakukan melalui $:^{25}$

1. Pemberian kewenangan terhadap suatu tindakan kepada lebih dari satu cabang pemerintahan

2. Pemberian kewenangan pengangkatan pejabat tertentu kepada lebih dari satu cabang pemerintahan.

3. Upaya hukum dari cabang pemerintahan yang satu terhadap cabang yang lainnya.

4. Pengawasan langsung dari satu cabang pemerintahan terhadap cabang pemerintahan lainnya.

5. Pemberian kewenangan kepada pengadilan sebagai pemutus kata akhir bila ada konflik kewenangan antara eksekutif dan legislatif.

Teori pemisahan kekuasaan Montesquieu mengalami perkembangan dan mendapat kritikan. Pemisahan kegiatan eksekutif, legislatif dan yudikatif tidak dapat dipisahkan secara tajam satu dengan yang lain. Menurut E. Utrecht, pemisahan mutlak yang dikemukakan oleh Montesquieu mengakibatkan adanya badan negara yang tidak ditempatkan di bawah pengawasan badan kenegaraan lainnya. Ketiadaan pengawasan ini mengakibatkan terbukanya kemungkinan suatu badan kenegaraan melampaui batas kekuasaannya. $^{26}$

Mariam Budiardjo menyatakan pada abad ke-20 dalam negara yang sedang berkembangan dimana kehidupan ekonomi dan sosial telah menjadi demikian kompleksnya serta badan eksekutif mengatur hampir semua aspek kehidupan

${ }^{23}$ Jimly Asshiddiqie, Struktur Ketatanegaraan Indonesia Setelah Perubahan Keempat UUD Tahun 1945, Makalah, Denpasar 14-18 Juli 2003, hlm. 2-3

${ }^{24}$ Miriam Budiardjo, Op.Cit., hlm. 282

${ }^{25}$ Ibid.,hlm.55

${ }^{26}$ Miriam Budiardjo, Ibid., hlm. 283 
kehidupan masyarakat, Trias Politika dalam arti "pemisahan kekuasaan" tidak dapat dipertahankan lagi. Selain itu, dewasa ini hampir semua negara modern mempunyai tujuan untuk kesejahteraan bagi seluruh rakyatnya (Welfare State). Untuk mencapai tujuan tersebut negara dituntut menjalan fungsi secara tepat, cepat dan komprehensip dari semua lembaga negara yang ada. ${ }^{27}$

\section{Teori Sistem Pemerintahan}

Harun Alrasyid menyatakan bahwa, sistem pemerintahan ialah sistem hukum ketatanegaraan, baik yang berbentuk monarki maupun republik yaitu mengenai hubungan antar pemerintah dan badan yang mewakili rakyat. Lebih lanjut Mexsasai mengutip pendapat dari Mahfud MD, bahwa sistem pemerintahan dipahami sebagai suatu sistem hubungan tata kerja antar lembaga-lembaga negara. ${ }^{28}$

Sebagai salah satu negara yang menerapkan demokrasi dalam melaksanakan pemerintahannya, Indonesia bisa dikatakan menganut sistem pemerintahan presidensial. Sistem presidensial (atau presidensil) merupakan sistem pemerintahan yang terpusat pada jabatan Presiden sebagai kepala pemerintahan (head of government) sekaligus sebagai kepala negara (head of state). ${ }^{29}$ Secara garis besar, ciriciri lembaga kepresidenan dalam sistem pemerintahan presidensial khususnya yang dianut di Indonesia setelah perubahan UUD 1945 adalah sebagai berikut:

1. Presiden ialah pemegang kekuasaan eksekutif tunggal;

2. Presiden ialah penyelenggara pemerintahan yang bertanggungjawab, di samping berbagai wewenang konstitusional yang bersifat prerogatif dan biasanya melekat pada jabatan kepala negara atau head of state;

3. Presiden tidak bertanggungjawab kepada Badan Perwakilan Rakyat;

4. Presiden tidak dipilih dan tidak diangkat oleh Badan Perwakilan Rakyat, akan tetapi dipilih langsung oleh rakyat;

5. Presiden memangku jabatan lima tahun, fixed, dan dapat dipilih kembali hanya untuk satu kali masa jabatan;

6. Presiden dapat diberhentikan dalam masa jabatan melalui impeachment, apabilan terbukti melanggar hukum berupa: (1) pengkhianatan terhadap negara; (2) korupsi; (3) penyuapan; (4) tindak pidana berat lainnya; (5) perbuatan tercela; dan (6) terbukti tidak lagi memenuhi syarat sebagai Presiden dan atau Wakil Presiden. Impeachment dapat diwujudkan hanya melalui Mahkamah Konstusi dan DPR. ${ }^{30}$

Kualifikasi tersebut memperlihatkan bahwa sistem pemerintahan presidensial tidak hanya meletakkan Presiden sebagai pusat kekuasaan eksekutif, tetapi juga

\footnotetext{
${ }^{27}$ Jimly Asshiddiqie, op.cit., hlm. 29-30

${ }^{28}$ Indra Mexsasai., "Dinamika Hukum Tata..." Op.Cit. hlm. 120-121

${ }^{29}$ Jimly Asshiddiqie, Pokok-Pokok..., Op. Cit., hlm. 311.

${ }^{30}$ Susilo Suharto, Kekuasaan Presiden RI dalam Periode Berlakunya UUD 1945, Yogyakarta: Graha Ilmu, 2006, hlm. 62.
} 
kekuasaan negara. Sebagaimana dikatakan Rett R. Ludwikowski "The President, as the soleexecutive, is elected as head of state and head of the government." 31

\section{METODE PENELITIAN}

Penelitian yang dilakukan ini menggunakan Jenis penelitian Yuridis-Normatif, yaitu penelitian yang bertujuan untuk menelaah asas hukum, sistematika hukum, sejarah hukum, dan sinkronisasi hukum. ${ }^{32}$ Soerjono Soekanto mengemukakan "Penelitian hukum yang dilakukan dengan cara meneliti bahan pustaka atau data sekunder belaka dapat dinamakan penelitian hukum normatif atau penelitian hukum kepustakaan. ${ }^{33}$ Ronny Hanitijo mengemukakan "Penelitian Hukum Normatif merupakan penelitian kepustakaan yaitu penelitian terhadap data sekunder. ${ }^{34}$

Pendekatan yuridis normatif dilakukan dengan cara meneliti bahan Pustaka atau data sekunder sebagai bahan dasar untuk diteliti. ${ }^{35}$ Melalui pendekatan tersebut, penulis menelaah hal-hal yang bersifat teoritis yang berkaitan dengan norma atau kaidah dasar, asas-asas dan teori hukum, doktrin, dan mengkaji sejarah pengaturan hukuman mati dalam peraturan perundang-undangan yang mencakup materi, substansi, kekuatan mengikat dan sinkronisasi peraturan perundang-undangan secara horisontal maupun vertical.

Data sekunder adalah data yang digunakan dalam penelitian ini. Yang dimaksud dari data sekunder adalah data-data yang diperoleh dari bahan pustaka. ${ }^{36}$, terdiri dari:

a. Bahan hukum primer

Bahan hukum primer adalah data yang berasal dengan melakukan studi literatur atau bahan pustaka dengan cara menelaah dari peraturan Perundang-Undangan serta peratura-peraturan yang berkaitan dengan materi penelitian, yaitu:

1) Undang-Undang Dasar Negara Republik Indonesia Tahun 1945

2) Undang-undang Nomor 2 Tahun 2002 tentang Kepolisian Negara Republik Indonesia

3) Ketetapan MPR No. VII/MPR/2000 Tentang Peran Tentara Nasional Indonesia dan Peran Kepolisian Negara Republik Indonesia

4) Peraturan Presiden No.52 Tahun 2010 Tentang Susunan Organisasi dan Tata Kerja Kepolisian Republik Indonesia

5) Peraturan Presiden No.17 Tahun 2005 Tentang Komisi Kepolisian Nasional

6) Peraturan Presiden No.17 Tahun 2011 Tentang Komisi Kepolisian Nasional

${ }^{31}$ Rett R. Ludwikowski, "Latin American Hybrid Constitutionalism: The United States Presidentialism in the Civil Law Melting Pot", Boston University International Law Journal, Volume 21 Nomor 29, Spring2003, Boston, MA: Boston University School of Law, 2003, hlm. 34.

${ }^{32}$ Soerjono Soekanto, Pengantar Penelitian Hukum, Op.Cit, hlm. 50.

${ }^{33}$ Soerjono Soekanto, Penelitian Hukum Normatif, Op.Cit.,, hlm. 15

${ }^{34}$ Ronny Hanitijo Soemitro, Metodologi Penelitian Hukum dan Jurimetri, Jakarta: Ghalia Indonesia, 1988, hlm. 11

${ }^{35}$ Soerjono Soekanto \& Sri Mamudji, Op.Cit., hlm. 13-14.

${ }^{36}$ Soerjono Soekanto dan Sri Mamudji, Op.Cit., hlm.12 
7) Peraturan Kepala Kepolisian Negara Republik Indonesia No.10 Tahun 2011 Tentang Pokok-Pokok Hubungan Tata Cara Kerja di Lingkungan Kepolisian Negara Republik Indonesia

8) Peraturan Kepolisian Negara Republik Indonesia No.3 Tahun 2018 Tentang Hubungan Tata Cara Kerja Kepolisian Negara Republik Indonesia

b. Bahan hukum sekunder

Yaitu bahan hukum yang memberi penjelasan terhadap bahan hukum primer, seperti makalah: buku, hasil lokakarya, seminar, simposium, diskusi, dan hasilhasil penelitian, tesis dan disertasi, serta tulisan-tulisan ilmiah lainnya yang ada hubungannya dengan obyek penelitian ini. Bahan hukum sekunder, yaitu bahan yang memberikan penjelasan lebih lanjut seperti penelitian dan hasil karya yang dilakukan dari kalangan pakar hukum. ${ }^{37}$

c. Bahan Hukum Tersier

Yaitu bahan yang memberi petunjuk maupun penjelasan terhadap bahan hukum primer dan sekunder, yaitu kamus hukum, kamus bahasa Indonesia, ensiklopedia, artikel-artikel pada majalah/Koran/internet dan sebagainya

Bahan hukum primer, sekunder dan tersier tersebut dikumpulkan berdasarkan topik permasalahan, kemudian dikaji secara komprehensif. ${ }^{38}$ Dalam rangka mengumpulkan data penelitian, untuk data sekunder peneliti langsung mengumpulkannya dari sumber bahan hukum primer, sekunder dan tersier. Dogmatika Hukum bersifat teoretis-rasional sehingga pengungkapannya terikat pada metode yang didasarkannya pada persyaratan logika deduktif. ${ }^{39}$ Sementara untuk penambahan penjelasan penulis menggali informasi dari narasumber yang berkompeten yaitu dari Kompolnas dan pemangku kepentingan Kepolisian lainnya.

\section{PEMBAHASAN}

Pasal 1 Ayat (3) UUD 1945 menyebutkan Indonesia adalah negara hukum. Ketentuan Pasal tersebut merupakan penegasan bahwa Indonesia menganut paham Negara hukum sebagai basis penyelenggaraan Negara. konsekuensi dari dianutnya paham Negara hukum tersebut adalah seluruh penyelenggaraan Negara dan pemerintahan tunduk pada ketentuan hukum yang berlaku.

Doktrin pemisahan kekuasaan (separation of power) yang menjiwai demokrasi diwujudkan salah satunya ke dalam ketentuan UUD 1945 yang mengatur tentang tugas dan wewenang lembaga-lembaga Negara dalam pemerintahan. Penyelenggaraan Negara Indonesia mengacu pada ketentuan UUD 1945 yang memberikan pedoman penyelenggaraan Negara yang menganut asas pemisahan kekuasaan dan mekanisme check and balance diantara kekuasaan eksekutif, legislatif dan yudikatif. Meskipun tidak secara implisit disebutkan mengenai pemisahan kekuasaan Negara tersebut namun dari tugas dan wewenang yang melekat pada organ Negara tersebut mengidentifikasikan karakter dan fungsinya dalam penyelenggaraan Negara.

${ }^{37}$ Ibid, hlm. 15.

${ }^{38}$ Jhonny Ibrahim, Teori dan Metodologi Penelitian Hukum Normatif, Malang: Bayumedia Publishing, 2012., hlm.282.

${ }^{39}$ Soerjono Soekanto, Penelitian Hukum Normatif, Op.Cit., hlm. 3 
Upaya untuk membangun mekanisme check and balances dalam struktur ketatanegaraan dan sistem pemerintahan Indonesia yang demokratis diterapkan dalam ruang lingkup yang sangat luas. Mekanisme checks and balances diterapkan dalam konteks relasi segenap organ negara baik organ negara utama maupun organ-organ negara penunjang (auxiliary state organ). Pembentukan organ negara penunjang adalah trend baru dalam kehidupan bernegara dan praktik penyelenggaraan negara di Indonesia pascaamademen UUD 1945. Organ-organ negara penunjang adalah organ negara yang menjalankan kekuasaan negara yang tidak serta merta termasuk dalam kategori salah satu cabang kekuasaan menurut doktrin klasik Trias Politica Montesquieu.

Keseluruhan organ-organ penyelenggara negara yang dibentuk pascaamandemen UUD 1945 dapat dibagi dalam 2 (dua) kategori. Pertama, organorgan penyelenggara negara kategori organ negara utama (main organ). Organ negara utama (main state organ) terdiri atas (1) MPR, (2) DPR. (3) DPD, (4) Presiden, (5) Mahkamah Agung, (6) Mahkamah Konstitusi dan (7) Badan Pemeriksa Keuangan. Kedua, organ-organ penyelenggara negara kategori organ negara penunjang (auxiliary state organ) yang disebut Jimly Asshiddiqie sebagai organ negara lapis kedua. ${ }^{40}$ Organ negara penunjang memperoleh kewenangan dari UUD 1945 atau undang-undang. Organ negara lapis kedua yang memperoleh kewenangannya dari UUD 1945 adalah (1) Komisi Yudisial, (2) Tentara Nasional Indonesia. Organ negara lapis kedua yang memperoleh kewenangannya dari undang-undang adalah (1) Komnas HAM (2) Komisi Penyiaran Indonesia dan lain-lain. Organ negara lapis kedua meliputi Menteri Negara, Tentara Nasional Indonesia, Kepolisian negara Republik Indonesia, Komisi Yudisial, Komisi Pemilihan Umum dan Bank Sentral. Kedudukan organ negara lapis kedua sejajar dengan organ negara yang dibentuk berdasarkan undang-undang seperti Komnas HAM, KPK, Komisi Penyiaran Indonesia, Komisi Pengawas Persaingan Usaha dan lain-lain.

Berdasarkan hal tersebut maka UUD 1945 hasil amandemen kedua pada Pasal 30 Ayat (4) menyebutkan bahwa Kepolisian Negara Republik Indonesia sebagai alat negara yang menjaga keamanan dan ketertiban masyarakat bertugas melindungi, mengayomi, melayani masyarakat, serta menegakkan hukum. Adapun susunan kedudukan Polri didalam menjalankan tugasnya diatur oleh Undang-undang. Sebagai lembaga Negara pembantu (state auxiliary organ), eksistensi dan pengaturan tentang Polri sangat komprehensif karena kedudukannya sudah diatur secara eksplisit dalam UUD 1945.

Kedudukan kepolisian tidak diatur secara jelas dan tegas dalam UUD 1945, lain halnya dengan Angkatan Darat, Angkatan Laut dan angkatan Udara yang diatur secara tegas dalam Pasal 10 UUD 1945, yakni "Presiden. memegang kekuasaan yang tertinggi atas Angkatan Darat, Angkatan Laut, dan Angkatan Udara". Akan tetapi ketentuan dalam Pasal 30 ayat (5) UUD 1945 mensyaratkan adanya tindak lanjut pembentukan Undang - Undang yang mengatur tentang susunan dan kedudukan, hubungan kewenangan Polri dalam menjalankan tugasnya sehingga konsekuensi logis dari ketentuan Pasal 30 ayat (5) UUD 1945. tersebut dibentuk Undang - undang No. 2 Tahun 2002 tentang : Polri, dimana di dalam Undang-undang dimaksud lembaga kepolisian diposisikan di bawah Presiden dan bertanggung jawab kepada Presiden.

\footnotetext{
40 Jimly Asshiddiqie, Penguatan Sistem Pemerintahan dan Peradilan , Jakarta: Sinar Grafika, 2015, hlm. 104
} 
Beberapa peraturan perundang-undangan, yakni Pasal 30 ayat (4) UUD 1945, Pasal 6 ayat (1) Ketetapan MPR RI No.VII/MPR/2000, dan Pasal 5 ayat (1) UU No. 2 Tahun 2002 tentang Kepolisian Negara Republik Indonesia mengatur kepolisian sebagai alat negara yang menjalankan salah satu fungsi pernerintahan terutama dibidang pemeliharaan keamanan dan ketertiban masyarakat. Adapun tugas pokok Polri dilakukan dengan memberikan Perlindungan, pengayoman dan pelayanan kepada masyarakat serta penegakan hukum. Konsekuensi dari menjalankan. Salah satu fungsi pemerintahan tersebut, maka kedudukan kepolisian berada di bawah Presiden yang secara ketatanegaraan tugas pemerintahan tersebut adalah merupakan tugas lembaga eksekutif yang dikepalai oleh Presiden. Dilihat dari ketatanegaraan berdasarkan UUD 1945 lembaga Kepolisian merupakan lembaga pernerintahan (regeringsorgtinen). Dengan pisahnya Tentara Nasional Indonesia dan Polri secara kelembagaan dapat dikatakan kepolisian sebagai lembaga administrasi (.administrative organen), karena tugas dibidang keamanandan ketertiban umum merupakan tugas dan wewenang administrasi.

Dari sekian banyak tugas Kepolisian yang mencakup bidang penegakkan hukum dan perlindungan masyarakat, diperlukan dukungan kelembagaan yang kuat meliputi struktur, SDM, pendanaan dan kebijakan yang strategis guna menunjang tugas dan fungsi Polri. Salah satu unsur penting dari keberhasilan Polri sebagai lembaga penegak hukum dalam negara hukum demokratis adalah pengawasan dari suatu lembaga pengawas eksternal untuk menjamin profesionalitas Polri.

Fenomena menguatnya praktik penyalahgunaan wewenang dan korupsi di internal Polri paska pemisahan dari ABRI mengindikasikan dua hal, yakni: Pertama, Polri pasca berpisah dari ABRI cenderung menjadi partikel bebas yang minim pengawasan dan kontrol; dan kedua, sebagai bagian dari eforia internal yang tidak berkesudahan paska berpisah dari ABRI. Sebagaimana diketahui bahwa era 38 tahun bersama-sama dalam struktur ABRI, adalah saatsaat dimana era kegelapan bagi Polri untuk berakselerasi, khususnya pada peran dan fungsinya sebagai penegak hukum dan Keamanan Dalam Negeri. Berpisahnya Polri dari ABRI dalam pandangan Adrianus Meliala banyak berimplikasi positif terhadap internal Polri. Akan tetapi tiak sedikit implikasi negatif yang makin menjerumuskan Polri dalam situasi yang tidak menguntungkan secara organisasi, salah satunya praktik-praktik korupsi yang menguat dari tingkat pusat hingga Pos Polisi. Selain pencitraan yang tidak kunjung membaik; juga fungsi pengawasan yang minim paska berpisah dari ABRI dan langsung di bawah Presiden. Keduanya saling berikat satu dengan yang lainnya. Karena pengawasan yang minim, maka peluang praktik-praktik korupsi dan penyalahgunaan wewenang menjadi marak dan masif. ${ }^{41}$

Berkaca pada kondisi tersebut, wacana peningkatan citra setelah berpisah dari ABRI mulai mendorong tekanan publik agar dibentuk lembaga kepolisian yang berfungsi melakukan pengawasan terhadap kinerja Polri. Oleh karena itu muncullah Lembaga Kepolisian Nasional (yang selanjutnya disebut Kompolnas). Kompolnas adalah lembaga kepolisian nasional yang berkedudukan di bawah dan bertanggung jawab kepada Presiden. Lembaga ini dibentuk pada awalnya berdasarkan Perpres No.17 Tahun 2005 yaitu pada masa kepemimpinan Presiden Susilo Bambang Yudhoyono. Keberadaan Komisi Kepolisian Nasional (Kompolnas) sebagai lembaga baru pada institusi Kepolisian Republik Indonesia (Polri) telah di atur dalam UU No.

41 Muradi, Polisi Paska Soeharto: Korupsi Mengalir Sampai Jauh, Jurnal Sosial Politik,Unpad,Vol.2 No.1 Tahun 2012, http://jurnal.unpad.ac.id/jsp/article/view/4099 
2 Tahun 2002 Tentang Kepolisian Negara Republik Indonesia. Hanya saja pembentukan Kompolnas baru dilakukan pada tahun 2006 dengan mengangkat para anggotanya dari berbagai unsur, yakni unsur pemerintahan, pakar kepolisian dan tokoh masyarakat. Pembentukan lembaga baru ini dimaksudkan agar dalam pembuatan kebijakan dibidang kepolisian memperoleh masukan dari unsur masyarakat. Kehadiran Kompolnas diharapkan dapat mengubah wajah kepolisian kita, yakni Kompolnas dapat menaikan citra polisi yang semakin jelek (bad police) menjadi polisi yang baik (good police). ${ }^{42}$

Keberadaan Kompolnas diatur dalam Peraturan Presiden (Perpres) Perpres No.17 Tahun 2005 Tentang Komisi Kepolisian Nasional yang kemudian diubah dengan Perpres No.17 Tahun 2011 Tentang Komisi Kepolisian Nasional. Pada Pasal 37 ayat (1) UU No.2 Tahun 2002 Tentang Kepolisian Republik Indonesia, disebutkan tentang Lembaga Kepolisian Nasional yang disebut dengan Komisi Kepolisian Nasional berkedudukan di bawah dan bertanggung jawab kepada Presiden, dan Ayat (2) UU No.2 Tahun 2002 Kepolisian Negara Republik Indonesia, Komisi Kepolisian Nasional sebagaimana dimaksud dalam ayat (1) dibentuk dengan Keputusan Presiden

Kemudian pada Pasal 38 Ayat (1) dan Ayat (2) UU No 2 Tahun 2002 tentang Polri yang mengatur tugas dan wewenang Kompolnas disebutkan bahwa tugas Kompolnas yaitu a) Membantu Presiden dalam menetapkan arah kebijakan Polri dan; b) Memberi pertimbangan kepada presiden dalam pengangkatan dan pemberhentian Kapolri. Kemudian dalam melaksanakan tugasnya Kompolnas berwenang untuk:

1) Mengumpulkan dan menganalisa data sebagai bahan pemberian saran kepada Presiden yang berkait dengan anggaran Polri, pengembangan sumber daya manusia Polri dan pengembangan sarana dan prasarana Polri;

2) memberikan saran dan pertimbangan lain kepada Presiden dalam upaya mewujudkan Polri yang profesional dan mandiri;

3) Menerima saran dan keluhan dari masyarakat mengenai kinerja Kepolisian dan menyampaikan kepada Presiden.

Fungsi Kompolnas menurut Perpres No. 17 Tahun 2011 termuat dalam Pasal 3 Ayat (1) Kompolnas melaksanakan fungsi pengawasan fungsional terhadap kinerja Polri untuk menjamin profesionalisme dan kemandirian Polri. Kemudian pada Ayat (2) Pelaksanaan fungsi pengawasan fungsional sebagaimana dimaksud dalam ayat (1) dilaksanakan melalui kegiatan pemantauan dan penilaian terhadap kinerja dan integritas anggota POLRI sesuai dengan ketentuan peraturan perundang-undangan.

Namun demikian, jika melihat Perpres No.17 Tahun 2011 Tentang Kompolnas, tidak terlihat penjabaran lebih detail materi muatan tentang tugas dan kewenangan kompolnas yang diamanatkan dalam UU No.2 Tahun 2002 tentang Kepolisian Republik Indonesia. Materi muatan tentang tentang tugas dan wewenang Kompolnas masih sama seperti yang diatur dalam UU No.2 Tahun 2002 tentang Kepolisian Republik Indonesia. Perpres No.17 Tahun 2011 tentang Kompolnas lebih terlihat sebagai tindakan Presiden yang merasa perlu memimpin pemerintahan dengan memastikan lembaga kepolisian nasional yang disebut Kompolnas dapat melaksanakan fungsi Kompolnas melaksanakan fungsi pengawasan fungsional terhadap kinerja Polri untuk menjamin profesionalisme dan kemandirian Polri. Mengenai fungsi kompolnas yang tidak diatur dalam UU No.2 Tahun 2002 Tentang

${ }^{42}$ Pudi Rahardi, Op.Cit, hlm 281 
Polri, tetapi diatur dalam Perpres No.17 Tahun 2011 tentang Kompolnas merupakan penjabaran peran kelembagaan yang strategis. Fungsi Kompolnas yang melaksanakan pengawasan fungsional terhadap kinerja Polri untuk menjamin profesionalitas dan kemandirian Polri telah menjadi semangat yang sebenarnya dari lembaga tersebut. Namun demikian fungsi pengawasan fungsional yang dinilai strategis bagi peningkatan kinerja Polri tersebut tidak bisa dilakukan dengan optimal dengan tugas dan wewenangnya saat ini.

Wewenang Kompolnas dalam menerima menerima saran dan keluhan dari masyarakat mengenai kinerja kepolisian dan menyampaikannya kepada Presiden, merupakan wewenang yang ambigu. Hal ini dikarenakan wewenang adalah kekuasaan untuk melakukan sesuatu yang diberikan oleh lembaga yang tinggi dalam menjalankan tugas dan fungsi. Namun demikian wewenang yang disebutkan tersebut lebih cenderung merupakan tugas yang menunjang fungsi pengawasan fungsional atas kinerja Polri untuk menjamin profesionalitas dan kemandirian Polri. Wewenang kompolnas dalam menerima menerima saran dan keluhan dari masyarakat terkait kinerja Polri memang dapat menjadi masukan dalam penyusunan arah kebijakan Polri. Namun kegiatan-kegiatan yang dilakukan dalam rangka memenuhi wewenang tersebut lebih bersifat teknis daripada strategis yang menunjang penyusunan arah kebijakan strategis Polri.

Berkaitan dengan aspirasi dan keluhan masyarakat terhadap kinerja Polri, Kompolnas mencatat sepanjang tahun 2019, Kompolnas menerima 2.159 pengaduan dari masyarakat pada 2017, Kompolnas menerima 3.211 aduan, sedangkan pada 2018 menerima 3.098 aduan. Meskipun mengalami penurunan jumlah pengaduan namun masih sedikit yang dapat ditangani dengan baik. Menurut Komisioner Kompolnas Poengky Indarti, rata-rata pengaduan masyarakat yang masuk, terbanyak adalah menyangkut dugaan pelayanan buruk, disusul dengan penyalahgunaan kewenangan, diskresi keliru, diskriminasi, dan korupsi. ${ }^{43}$ Sementara pengaduan pelayanan buruk menurut komisioner Kompolnas lainnya Andrea Poeloengan 94 persen dari seluruh keluhan yang diterima Kompolnas mengeluhkan tentang fungsi Reserse. Setelah diklarifikasi oleh Kompolnas, rata rata yang dapat dibuktikan ada kesalahan oleh penyidik dalam proses penanganan perkara sekitar 5-6 persen. ${ }^{44}$

Melihat komposisi tugas dan wewenang Kompolnas, hal ini menjadi jelas dan kelihatan sekali, bahwa pengawasan kinerja Kepolisian dengan indikator keluhan masyarakat sudah resmi dan efisien sebenarnya, namun saat ini Sosialisasi Kompolnas ke daerah- daerah lain tidak maksimal dan kurang diketahuui keberadaannya oleh masyarakat. Masyarakat di kabupatenkabupaten banyak yang belum mengetahui, karena Kompolnas tidak pernah melakukan sosialisasi dan memberikan keterangan kepada media massa akan keberadaannya. Justru Lembaga-lembaga lain yang sebenarnya boleh dikatakan tidak mempunyai landasan hukum yang kuat untuk menilai Polri secara objektif seperti lembaga-lembaga Swadaya Masyarakat, Lembaga Survey, yang sering mempublikasikan hasil temuannya di media massa yang terkadang diragukan keobjektifitasannya. Untuk itu, sebaiknya dalam proses pengawasan Polri di masa mendatang, sebaiknya Kompolnas melakukan tugasnya dan

43 https://nasional.kompas.com/read/2019/07/03/07450871/keluhan-masyarakat-turun-polridinilai-kompolnas-bekerja-lebih-

baik\#: :text=JAKARTA\%2C\%20KOMPAS.com\%20\%2D\%20Komisi,selama\%20Januari\%20hingga $\frac{\% 20 \mathrm{Juni} \% 202019}{44}$.

https://pojoksatu.id/news/berita-nasional/2020/01/09/ribuan-polisi-diadukan-kekompolnas-cuma-segini-yang-terbukti-salah/ 
berperan dalam pembuatan opini publik yang dipercaya dan diterima oleh hukum dan masyarakat. Kompolnas semestinya menjadi ujung tombak dalam memberikan informasi yang berkaitan dengan Kinerja Polri dan dapat dijadikan tolak ukur atau indikator keberhasilan pelaksanaan tugas pokok Polri.

Dengan kedudukan dan struktur keanggotaan Kompolnas dan mekanisme kerja yang berkaitan wewenang yang dimiliki saat ini, kompolnas belum mampu menjalankan tugas dan fungsinya dengan baik. Hal ini berkaitan dengan lemahnya wewenang yang dimiliki Kompolnas. Menurut Andrea Poeloengan ada tiga cara yang dilakukan Kompolnas untuk menindaklanjuti setiap pengaduan dari masyarakat. Pertama, bersurat ke Irwasda. Kedua, melakukan klarifikasi dengan mendatangi Polda dan difasilitasi oleh Itwasda. Ketiga, melakukan supervisi untuk mengetahui progres dari klarifikasi yang telah dilakukan.

Namun demikian banyaknya kegiatan yang termasuk kedalam lingkup wewenang Kompolnas tidak bisa dilaksanakan semua. Hal ini disebabkan karena wewenang pokok Kompolnas yang sangat terbatas dalam melakukan aktifitas pemantauan dalam makna pengawasan internal kinerja Polri (termasuk anggotaanggota Polri di setiap tingkatan. Selain itu faktor politis dan teknis organisasi Kompolnas dengan Kapolri yang berbeda menyebabkan cara-cara yang dilakukan komisioner untuk menindaklanjuti keluhan masyarakat menjadi terbatas.

Setelah mengetahui tugas dan wewenang oleh Kompolnas seperti yang tertuang dalam Perpres No.17 Tahun 2011 tentang Kompolnas, diketahui bahwa dengan tugas dan wewenang yang dimiliki saat ini tidak akan mampu menjalankan tugasnya dalam menetapkan arah kebijakan Polri dan memberikan pertimbangan kepada Presiden dalam pengangkatan dan pemberhentian Kapolri. Ada beberapa hal yang mendasari argumentasi tersebut, Pertama, tugas-tugas yang diamanatkan dalam Perpres No.17 Tahun 2011 terlalu abstrak untuk dilaksanakan dengan wewenang yang terbatas. Hasil pemantauan dan evaluasi terhadap kinerja Polri tidak akan dapat menghasilkan capaian yang mengikat. Sebagai subjek hukum Kompolnas seharusnya dapat melakukan hubungan hukum yang menimbulkan akibat hukum, namun demikian usulan atau rekomendasi Kompolnas tidak bersifat mengikat terhadap Polri sebagai obyek pemantauan kinerja kepolisian tersebut. Usulan atau rekomendasi Kompolnas tidak akan memberikan efek yang menentukan hasil akhir atas dalam penyusunan arah kebijakan strategis Polri maupun dalam memberikan pertimbangan pengangkatan dan pemberhentian Kapolri.

Kedua, fungsi pengawasan eksternal yang menjadi cita-cita dan implementasi mekanisme check and balance dengan Polri tidak akan terlaksana dengan baik, karena kedudukan yang tidak seimbang antara kompolnas dengan Polri. Kedudukan kompolnas yang sama-sama berada di bawah Presiden namun dengan dasar hukum yang berbeda dengan Polri akan menyulitkan terlaksananya pengawasan eksternal terhadap kepolisian. Dasar hukum pembentukan Kompolnas yang dibentuk berdasarkan Perpres sangat tidak stabil karena Presiden dapat sewaktu-waktu membubarkan Kompolnas. Dengan demikian konsep penguatan penyelenggaraan pemerintahan dalam bidang perpolisian tidak akan dapat diwujudkan secara komprehensif dan atau langgeng dan berkelanjutan karena sangat tergantung pada kehendak politik Presiden yang membentuk lembaga ini.

Ketiga, secara filosofis ketika tugas dan wewenang kompolnas tidak mampu mendukung fungsi pengawasan eksternal, maka keberadaan Kompolnas tidak memiliki kemanfaatan dalam menunjang demokratisasi penyelenggaraan 
pemerintahan khususnya Polri. Padahal salah satu tujuan pemisahan kekuasaan adalah untuk mengurangi konsentrasi kekuasaan dan wewenang yang terlalu besar pada satu organ. Ketika Kompolnas tidak memiliki wewenang yang kuat untuk melaksanakan tugasnya maka fungsi lembaga penyeimbang yang dibentuk tidak akan berfungsi optimal, dan lebih sekedar pencitraan politik semata.

\section{KESIMPULAN}

Wewenang dan tugas Kompolnas saat ini belum mampu membuat Kompolnas dapat menjalankan tugasnya dalam menetapkan arah kebijakan POLRI dan memberikan pertimbangan kepada presiden dalam pengangkatan dan pemberhentian Kapolri. Tugas dan wewenang Kompolnas saat ini belum mampu membuat Kompolnas dapat menjalankan fungsinya sebagai lembaga Negara pembantu dalam pengawasan kinerja Polri. Kedudukan Kompolnas yang berada di bawah Presiden menyulitkan posisi Kompolnas dalam melakukan check and balances terhadap Polri.

Tugas kompolnas saat ini tidak mendukung fungsi pengawasan fungsional atas kinerja Polri karena tugas tersebut terlampau abstrak untuk bisa melakukan pengawasan efektif. Tugas kompolnas terlalu sederhana dalam mendukung pengawasan fungsional karena kedudukan kompolnas dan Polri yang sama-sama di bawah Presiden sebagai pemegang kekuasaan eksekutif menyulitkan Kompolnas memberikan penilaian obyektif terhadap Polri.

Adapun wewenang yang dimiliki Kompolnas saat ini tidak mendukung tugas Kompolnas untuk berfungi sebagai pengawas fungsional atas kinerja dan tugas pokok Polri. Hal ini disebabkan lemahnya wewenang yang dimiliki kompolnas tidak sebanding dengan fungsi lembaga yang diemban. Wewenang yang dimiliki Kompolnas saat ini masih terbatas pada wilayah teknis pemantauan yang tidak memiliki kekuatan hukum untuk menindaklanjuti hasil pemantauan dan evaluasi terhadap arah kebijakan strategis Polri.

Kompolnas tidak sebanding dengan fungsi lembaga yang diemban. Wewenang yang dimiliki Kompolnas saat ini masih terbatas pada wilayah teknis pemantauan yang tidak memiliki kekuatan hukum untuk menindaklanjuti hasil pemantauan dan evaluasi terhadap arah kebijakan strategis Polri.

Perubahan dan penambahan tugas serta wewenang yang diperlukan Kompolnas adalah tugas dan wewenang yang seharusnya dimiliki oleh lembaga Negara otonom yang independen. Perubahan kedudukan tugas dan wewenang yang mendukung independensi fungsi pengawasan eksternal tersebut harus dilakukan melalui peningkatan status kompolnas dalam suatu UU tersendiri. Perubahan tugas kompolnas ke depan semestinya diabdikan untuk melakukan pengawasan fungsional terhadap kinerja Polri untuk menjamin profesionalitas dan kemandirian Polri. Adapun kewenangan yang perlu ditambah dalam rangka memperluas wewenang Kompolnas yaitu pertama kewenangan eksekutorial pada temuan dugaan pelanggaran kode etik anggota Polri dari tingkat Mabes Polri sampai tingkat Polres. Kedua, kewenangan untuk menindaklanjuti hasil temuan atas saran dan keluhan masyarakat sebagai bahan pertimbangan penyusunan arah kebijakan strategis Polri dan memberikan rekomendasi yang mengikat atas hasil evaluasi pelaksanaan kebijakan teknis Polri. Ketiga, untuk memperkuat kewenangan Kompolnas, struktur dan keanggotaan Kompolnas perlu diubah dengan menghilangkan perwakilan Pemerintah (Menteri Kordinator Politik, Hukum dan Keamanan, Menteri Dalam Negeri, dan Menteri Hukum dan HAM) dan 
menggantinya dengan penambahan keanggotaan komisioner kompolnas dari unsur masyarakat. Dengan struktur dan keanggotaan komisioner yang terdiri dari masyarakat diharapkan aspirasi masyarakat akan lebih terdengar dan meminimalisir intervensi dari pemerintah guna mewujudkan pengawasan kepolisian secara partisipatif

\section{DAFTAR PUSTAKA}

Azhary, Negara Hukum Indonesia Analisis Normatif tentang Unsur-unsurnya, Cet. I, Jakarta: UI Press, 1995.

Firmansyah Arifin d.k.k., Lembaga Negara dan Sengketa Kewenangan Antarlembaga Negara Jakarta: Konsorsium Reformasi Hukum Nasional, 2005.

Komisi Kepolisian Nasional, Penilaian Stakeholders Terhadap Kinerja Kompolnas Tahun 2010 Jakarta: Kompolnas, 2010.

Titik Triwulan Tutik, Pokok-pokok Hukum Tata Negara Indonesia, Jakarta: Prestasi Pustaka, 2006.

Moh. Kusnardi, Hukum Tata Negara Indonesia, Jakarta: Sinar Bakti, 1987.

Hotma P. Sibuea, Asas Negara Hukum, Peraturan Kebijakan dan Asas-asas Umum Pemerintahan Yang Baik, Jakarta: Erlangga, 2010.

Mexsasai Indra, Dinamika Hukum Tata Negara Indonesia, Bandung: Refika Aditama, 2011.

Majda El. Muhtaj, Hak Asasi Manusia dalam Konstitusi Indonesia, Jakarta: Kencana, 2005.

Philipus Hadjon, Perlindungan Hukum bagi Rakyat di Indonesia, Jakarta: Bina Ilmu, 1987.

Jimly Assiddiqie, Gagasan Negara Hukum Indonesia, https://pngunungsitoli.go.id/assets/image/files/Konsep_Negara_Hukum_Indonesia.pdf, diakses pada tanggal 2 juli 2020, pukul 01:32 WIB.

Diana Halim Koentjoro, Hukum Administrasi Negara, Bogor Selatan: Ghalia Indonesia, 2004.

Hotma P Sibuea, Kapita Selekta Hukum Tata Negara, Jakarta: ATA.Print, 2007.

Janedjri M. Gaffar, Demokrasi Konstitusional: Praktik KetatanegaraanIndonesia SetelahPerubahan UUD 1945, Jakarta: Konstitusi Press, 2012.

Jimly Asshiddiqie, Pengantar Ilmu Hukum Tata Negara, Jakarta: Rajawali Pers, 2014.

Hotma P. Sibuea, Ilmu Negara, Jakarta:Erlangga, 2014.

Francis Sejersted, "Democracy and the Rule of Law: Some Historical Experiences of Contradictions in the Striving for Good Government", dalam Constitutionalism and Democracy (Edited by Jon Elster and Rune Slagstad), Cambridge, UK: Cambridge University Press, 1997.

Bagir Manan, Pertumbuhan dan Perkembangan Konstitusi Suatu Negara, Bandung: Mandar Maju,, 1995. 
Jimly Asshiddiqie, Struktur Ketatanegaraan Indonesia Setelah Perubahan Keempat UUD Tahun 1945, Makalah, Denpasar 14-18 Juli 2003.

Susilo Suharto, Kekuasaan Presiden RI dalam Periode Berlakunya UUD 1945, Yogyakarta: Graha Ilmu, 2006.

Rett R. Ludwikowski, "Latin American Hybrid Constitutionalism: The United States Presidentialism in the Civil Law Melting Pot", Boston University International Law Journal, Volume 21 Nomor 29, Spring2003, Boston, MA: Boston University School of Law, 2003.

Ronny Hanitijo Soemitro, Metodologi Penelitian Hukum dan Jurimetri, Jakarta: Ghalia Indonesia, 1988.

Jhonny Ibrahim, Teori dan Metodologi Penelitian Hukum Normatif, Malang: Bayumedia Publishing, 2012.

Jimly Asshiddiqie, Penguatan Sistem Pemerintahan dan Peradilan , Jakarta: Sinar Grafika, 2015

Muradi, Polisi Paska Soeharto: Korupsi Mengalir Sampai Jauh, Jurnal Sosial Politik,Unpad,Vol.2 No.1 Tahun 2012 , http://jurnal.unpad.ac.id/jsp/article/view/4099

https://nasional.kompas.com/read/2019/07/03/07450871/keluhan-masyarakat-turunpolri-dinilai-kompolnas-bekerja-lebihbaik\#: :text=JAKARTA\%2C\%20KOMPAS.com\%20\%2D\%20Komisi,selam a\%20Januari\%20hingga\%20Juni\%202019.

https://pojoksatu.id/news/berita-nasional/2020/01/09/ribuan-polisi-diadukan-kekompolnas-cuma-segini-yang-terbukti-salah/ 